\title{
Stalking of social healthcare workers: Preliminary results of a study conducted in Sardinia, Italy
}

\author{
Francesca Manunza, ${ }^{1}$ Vincenzo M. Mastronardi, ${ }^{2}$ Monica Calderaro ${ }^{3}$ \\ ${ }^{1}$ Medical Director Psychiatrist, ATS Sardinia, Psychotherapist, Criminologist, Forensic Psychopathologist; ${ }^{2}$ Former \\ Director of the Department of Forensic Psychopathology, First Faculty of Medicine, Department of Neurology and \\ Psychiatry Sapienza University of Rome; Director of the master's in criminology criminal system, Forensic \\ Psychopathology, Investigations and Security, Unint - University of International Studies of Rome; ${ }^{3}$ Criminologist \\ International PhD, Doctor in Clinical Psychology, Graphologist and teacher responsible for the training course in \\ Graphological Forensic, Sapienza University of Rome; Professor in the Master in Criminology, Unint - University of \\ International Studies of Rome; Researcher International Institute of Criminological and Forensic Psychopathology, Tutor \\ criminological disciplinary area, Telematic University of Rome, Unitelma Sapienza, Rome, Italy
}

\begin{abstract}
Several studies have highlighted that particular social and professional categories are at higher risk of being victim of stalking. Physicians and healthcare workers in general are at risk of being harassed while practising their profession, especially by their patients; this risk has been shown to be higher for psychiatrists and psychotherapists. According to a recent study, $21 \%$ of psychiatrists has been a victim of stalking; length of stalking behaviour on healthcare workers varies from a few weeks to several years. Aim of the present work is to gain a better understanding and a highlight on the frequency with which stalking occurs toward social and healthcare workers of public health facilities in Sardinia. After a review of literature, an anonymous questionnaire, prepared ad-hoc, has been administered to a sample of 265 healthcare workers in Sardinia: out of the 210 who have answered, we have taken into consideration 187 healthcare workers, have excluded 23 operators (psychiatric rehabilitators, professional educators, social workers) and chosen to analyze victimization suffered by psychiatrists, psychologists, nurses, social healthcare workers. In our sample the subjects who reported harassments comparable to the crime of stalking are represented by 30 healthcare workers out of the total sample of $187(16 \%)$. Females are the most frequently represented with a ratio of $23 / 30(77 \%)$ compared to males $7 / 30(23 \%)$. The risk of being a victim of harassment was higher for the group of psychiatrists and psychologists than for nurses. Among the victims, 18 were psychiatrists (60\%), 3 psychologists (10\%), and 9 nurses (30\%). Healthcare professionals are at high risk of victimization. The main tool available to the services is the team approach to multi-problematic cases, avoiding isolation of the dyad designated operator-patient. The feeling of impotence and isolation that is frequent in the victims of stalking, as shown also in our sample, is highlighted by several studies in which $10 \%$ of the victims interviewed claims to have thoughts of suicide as a way out.
\end{abstract}

\section{RIASSUNTO}

Diversi studi hanno posto in evidenza come per particolari categorie sociali e professionali esista un maggior rischio di essere vittima di stalking. I medici e i professionisti della salute in genere sono a rischio di subire molestie durante l'esercizio della loro professione, in particolare da parte dei loro pazienti; tale rischio si è evidenziato maggiore per psichiatri e psicoterapeuti. Secondo studi precedenti, il $21 \%$ degli psichiatri è stato vittima di stalking, la durata dei comportamenti di stalking sugli operatori della Salute Mentale va da qualche settimana a diversi anni. Il lavoro si propone di ottenere una maggiore comprensione e rappresentazione della frequenza con cui le Molestie Assillanti si verificano nei confronti di operatori sociosanitari di strutture pubbliche in Sardegna. È stato somministrato un questionario anonimo, preparato ad hoc, dopo una rassegna della letteratura, ad un campione di (265) operatori della Salute Mentale della Sardegna: di questi hanno risposto (210), di essi abbiamo considerato (187) operatori, (esclusi 23 operatori: riabilitatori psichiatrici, educatori professionali, assistenti sociali) e scelto di studiare la vittimizzazione subita da medici psichiatri, psicologi, infermieri, operatori sociosanitari. Nel nostro campione i soggetti che hanno segnalato molestie assimilabili al reato di stalking sono rappresentati da $\mathrm{n}=30$ operatori su $\mathrm{n}=187 \mathrm{del}$ campione totale $(16 \%)$. Il sesso femminile risulta maggiormente rappresentato con $\mathrm{F}=23 / 30(77 \%)$ rispetto a quello maschile M 7/30 (23\%). Il rischio di essere vittima di molestie è risultato maggiore per il gruppo di psichiatri e psicologi rispetto agli infermieri. Tra le vittime $\mathrm{n}=18$ erano medici psichiatri $(60 \%), \mathrm{n}=3$ psicologi $(10 \%), \mathrm{n}=9$ infermieri (30\%). I professionisti della salute mentale sono ad elevato rischio di vittimizzazione. Lo strumento principale a disposizione dei servizi è l'approccio d'équipe ai casi multiproblematici evitando che la diade operatore designato e paziente si isoli. La sensazione d'impotenza ed isolamento che frequentemente è presente nelle vittime di stalking, anche nel nostro campione, viene evidenziata da diversi studi in cui il (10\%) delle vittime intervistate dichiara di aver pensato al suicidio come via d'uscita.

\section{RESUME}

Diferentes estudios han evidenciado como, en relación a particulares categorías sociales y laborales, hay mayor riesgo de ser víctimas por el fenómeno de acoso. Los médicos y los demás profesionales de la salud corren el riesgo de sufrir acosos mientras ejercen su profesión, particularmente por parte de sus pacientes; dicho riesgo resultó mayor para psiquiatras y psicoterapeutas. (Según un estudio reciente, el $21 \%$ de los psiquiatras ha sido víctima de acoso, el tiempo de los acosos en contra de los operadores de Salud Mental dilata entre unas semanas y varios años. El trabajo apunta a conseguir un mayor conocimiento y descripción de la frecuencia con que los acosos hostigadores 
se presentan hacia los operadores socio terapéuticos de estructuras públicas en Cerdeña. De manera anónima se entregó una encuesta directamente enfocada, en ocasión de un convenio sobre el tema, a una muestra de referencia de 265 operadores de la Salud Mental de Cerdeña: los que contestaron fueron 210, entre ellos hemos considerado 187 operadores, hemos excluido 23 operadores: rehabilitadores psiquiátricos, educadores profesionales, asistentes sociales) y elegido de analizar la persecución sufrida por médicos psiquiatras, psicólogos, enfermeros, operadores socio sanitarios.

\section{Introduction}

The analysis of the international scientific literature concerning the characteristics of stalking leads to the definition of the same as an interpersonal behaviour of threat or harassment toward a specific subject, aimed at establishing a relationship, that is repeated several times over time and/or is characterized by a particular intensity, and is perceived as a disturbing factor by the victim (Caretti V., Ciulla S., Schimmenti A. 2011, p. 6).

Stalking can be referred to as the presence of three key elements, a harassing molester, repeated intrusive actions (of various types), and a victim who is disturbed, annoyed or alarmed by such behaviours (Galeazzi G.M., Curci P., Secchi C., 2003). In the perception of the intensity of stalking and definition of the same, the victim's character, tolerance, reactivity are determinant factors (Galeazzi G.M., Curci P., Secchi C., 2003). The stalker can implement intrusive behaviours, in the belief that they will be appreciated by the victim, either immediately or in the future and do not necessarily act with the aim of arousing fear or anxiety (Galeazzi G.M., Curci P., Secchi C., 2003).

Several studies have shown that for particular social and professional categories there is a higher risk of being a victim of stalking. A professional relationship can constitute a favourable ground on which misunderstandings may arise at the origin of the stalking behaviours, they provide for a certain setting within which the interaction between individuals is legitimized and preserved; however, there is a certain degree of intimacy implied in the nature of the relationship itself. Therefore, the mental health professional, getting in contact with the most intimate needs of the assisted person, requests for help and affection of people, who are alone and/or suffer from some disorders, can easily become object of projections. Resentment due to misunderstanding with the patient, therapeutic relationship of reliance and empathy, which is wrongly interpreted as a personal sentimental interest rather than as an attention of exclusive professional nature may also be a cause of stalking (Curci P. et al. 2003, Grattagliano I. et al., 2014, Merzagora Betsos I. et al., 2010, Pathè M, Mullen and Purcell M. 2002, Praus P. 2017 from Sandberg DA 2002 et al., and Faber SK, 2015). Conditions of vulnerability in the relational context (social isolation, emotional immaturity, low levels of social skills, pathological traits of personality) predispose the patient or the hypothetical stalker to misunderstandings (Galeazzi M. and Curci P., 2003, p. 159).

The studies performed by Gagliardi M. et al., in 2013 highlight that the risk of stalking among healthcare workers ranges from 3 to 24\% (From Sacco E. 2015, from Gagliardi GM. et al., 2013). McIvor RJ and colleagues report that $21 \%$ of psychiatrists has been a victim of stalking and that stalking length on mental health workers ranges from a few weeks to several years (Ostermeyer B. et al., 2016 from McIvor R. et al., 2008).

The most frequent reasons for stalking toward professionals, in the medical field, may be the resentment for medical-surgical treatments or interventions not considered satisfactory, or even "the feeling of being rejected or misunderstood". Negative feelings such as anger and hate for the interruption of a therapeutic relationship, either psychiatric or psychotherapeutic, possibly due to the first signs of the setting violation by the patient, may be another cause of stalking (Praus P. et al., 2017).

The most common types of stalkers detected in those harassing healthcare workers are the "incompetent" and the "rancorous" (From Da Sacco E., 2015, p. 14, from Purcell R., Powell MB and Mullen, 2005).

Rancorous or resentful stalkers act in response to a real or supposed insult or offense, driven by the desire to take revenge for a wrong, with actions aimed at persecuting the victim, by virtue of a legitimate claim of their own reasoning. The sense of control and power developed on the victim constitutes a positive reinforcement for the stalker (Galeazzi G.M. and Curci P., 2003).

Incompetent stalkers are those who would like to court a possible partner, but use inadequate, inefficient or counterproductive strategies. Among all the types of stalkers, incompetent harassers are likely to relapse, quickly change target when have failed with one and implement stalking behaviours toward more victims (Stefanelli M., 2011, Galeazzi G.M. and Curci P., 2003). According to some authors, it seems that the stalker's search for intimacy is frequently reported by the victims as a supposed motivation for stalking (Galeazzi G.M. and Curci P., 2003; Whyte S. et al., 2011); often the relationship with the psychiatrist or psychologist constitutes a meaningful relationship for the patient, for some patients the only one actually existing (particularly lonely persons and without affective relationships) (Galeazzi G.M. and Curci P., 2003). Sometimes mental health workers are required to take care of the victims of stalking, becoming themselves victims of this crime (Ostermeyer B. et al., 2016, page 670).

Harassments suffered by mental health workers are usually unwanted telephone calls, letters and direct contact, threats, chases, being spied on or subject to monitoring (Ostermeyer B. et al., 2016, p. 670 from Hughes FA et al., 2007). Telephone calls being an easy and cheap way of communication, represent the most common means used for harassment; some studies report that $50-75 \%$ of victims of stalking receive repeated unwanted phone calls, at any time of the day, both at home and at the workplace that interrupt their normal activities. For many stalkers it is the only type of harassment used, even for short and intense periods of time (Galeazzi G.M. and Curci P., 2003). Various researches have shown that women are more likely to call their victims and stalk them through e-mails or letters; it has been noted that women are less likely to follow their victims than men (Purcell R. 2001, Strand S. McEwan T, 2012, Ostermeyer B. et al., 2016). The incidence of female stalking is particularly relevant in specific professional settings, first and foremost the psychotherapeutic one where, according to the results of some studies, gender differences decrease until they disappear altogether; in this context there are more female stalkers that men, thus suggesting that such phenomenon is more common in women. (Alfarano E. et al., 2012). It has been reported that $40 \%$ of women stalk professionals they have already been in contact with (teachers, lawyers, doctors, mental healthcare workers) (Dressing H. et al., 2006). Female stalkers, more frequently than men, tend to persecute persons they 
already know, with whom they have had a professional relationship (Pomilla A., D'Argenio A., Mastronardi V. 2012; Ostermeyer B. et al., 2016).

Particularly interesting are also the data reported by Gentile S.R, Asamen J.K, Harmell P., and Weathers R., 2002 in their study conducted on 294 members of the American Psychological Association, in which $10.2 \%$ of the professionals report to have been stalked by their patients: females were $68 \%$ of cases. The most frequent diagnoses made by the psychologists themselves were Mood Disorders (62\% of cases) and Personality Disorders ( $75 \%$ of cases) (Alfarano E. 2012 from Gentile SR, 2002). In the year before the beginning of stalking many female stalkers had suffered a significant loss (Catanesi R. et al., 2013, Ostermeyer B. et al., 2016 by Meloy J and Boyd C., 2003). Clinicians may also become victims of a particular type of behaviour, the so called "stalking by proxy" (Sorrentino R., 2016). In this form of stalking the stalker, besides using the traditional methods of stalking, hires third parties who make complaints against professionals (e.g. through the administration or management of the hospital where the psychiatrist works, the police, the media, the court for human rights, the colleagues, the civil courts, or other ways). These third persons are unaware of the stalkers' background, follow their cause becoming stalker by proxy (Galeazzi G.M. and Curci P., 2003). When a complaint is resolved, further complaints take place. More rarely, stalking to healthcare workers can go beyond harassment and involve serious physical violence. A study conducted by Mastronardi V. and other colleagues in 2013 highlights that more than $20 \%$ of psychiatrists victims of stalking had been physically assaulted. Compared to the stalkers of the general population, some studies, besides the present survey, point out that the rate of physical violence and threats in stalking in this professional field is lower than that found in psychiatric and forensic samples; this could be due to the higher prevalence in this context of harassments seeking intimacy usually less violent, as well as to the higher amount of patients affected by psychosis who, according to various researches, are less likely to implement violent behaviours. Studies on groups of victims in the professional field report psychosis rates between 25 and $45 \%$ (Purcell R. et al., 2005; McIvor RJ et al., 2008; McEwan TE, and Strand S., 2013 from Abrams K. M. and Robinson G. E., 2011, Morgane R. K. and Kavanaugh K.D., 2011), while studies on stalking toward famous people show rates of psychosis of over $80 \%$ (McEwan TE and Strand S., 2013 from James et al., 2009). In fact, according to literature, psychotic stalkers are less likely to be violent than non-psychotic stalkers (Racine C. et al., 2014, Galeazzi G.M. and Curci P., 2003, Farnham F., James D., Cantrell P., 2000). Following stalking, besides the physical harm, psychiatrists complain also anxiety and fear (65\%), sleep disorders, anhedonia, poor motivation, health problems $(37 \%)$ as well as symptoms of Mental Disorders (5\%) (Whyte S. 2011, Maclean L. et al., 2013).

Since the subjective perception suffered by the victim of the traumatic event can mediate its effect, it is likely that the psychological and emotional reactions of psychiatrists who suffer harassment, both from patients and other types of stalkers, are influenced by the motivations that the healthcare workers deem are the cause of the stalking behaviour (Maclean L. et al., 2013). In the professional field, it is possible that psychiatrists believe that stalking is an expected event, in consideration of their particular work and, therefore, consider it less threatening. There is no evidence that psychiatrists are more or less likely to have negative psychological or psychiatric consequences than other victims of stalking; however, they may be considered less vulnerable to the consequences of stalking and, therefore, receive less support (Maclean L. et al. al. 2013).

\section{Materials and Methods}

In order to assess the incidence of the phenomenon of stalking in healthcare environments, after a review of the literature, we administered an anonymous questionnaire, prepared ad hoc, (to be filled in autonomously) to a sample of healthcare workers in Sardinia. It was first administered throughout the Department of Mental Health and Addictions of the Local Healthcare Area of Carbonia, Iglesias, San Gavino, Sanluri, Guspin, and then the research was extended to the Department of Mental Health and Addictions of Lanusei-Nuoro ${ }^{1}$ and the Department of Mental Health of Cagliari. ${ }^{1}$

From our sample we have analyzed the socio-demographic characteristics, those related to the professional seniority, the work context (Mental Health Center, Serd, Spdc) and the role (the participants were grouped into three categories: Physicians, Psychiatrists, Psychologists and Others). In the first section of the questionnaire we included a screening page, in which healthcare workers are asked if, during their professional activity, they had ever been victims of stalking. In the affirmative case, four further sections were planned to analyze the characteristics of the Stalker: sociodemographic data, psychiatric diagnosis; the Stalking: type and length of harassment; the Victim: any physical, emotional and psychological reactions reported as a consequence of stalking and finally, in the last section, the behavioural strategies adopted to contrast such phenomenon. The high rate of responses (210) out of 265 operators to whom the questionnaire has been administered confirms how interesting and relevant is the topic for the studied population.

\section{Results}

\section{Total sample}

Out of 210 healthcare workers of Sardinia who participated in the study we considered 187 operators (we excluded 23 operators: psychiatric rehabilitators, professional educators, social workers) and chose to study the victimization suffered by physicians, psychiatrists, psychologists, nurses, social and health workers. Our sample of 187 mental healthcare workers consists of 121 female healthcare workers $(65 \%)$ and 66 male $(35 \%)$. The healthcare workers included: 67 physicians $(35,5 \%)$ of whom $66(35 \%)$ were psychiatrists, plus 1 who was an internist doctor $(0.53 \%), 20$ psychologists $(10.70 \%), 99$ nurses $(52.66 \%)$ : among these 89 (47.34\%) were professional nurses, plus 10 Social Health Operator $(5.35 \%) ; 1$ healthcare worker did not declare the professional category she belonged to $(0.53 \%)$. The average age of the total sample of the professionals examined was 51 years.

In addition to the Department of Mental Health and Addictions of the Local Healthcare Area of Carbonia, Iglesias, San Gavino, Sanluri, Guspini.(4 Health Care Centers, 3= Serd, Spdc, Rems); the Department of Mental Health and Addictions of Lanusei-Nuoro (Csm Lanusei, Csm Nuoro and Serd Tortoli) and the Department of Mental Health of Cagliari (Forensic Psychiatry Service of Cagliari, Csm Cagliari West, Csm Assemini, Csm and Serd Quartu Sant'Elena ). We would like to thank the Heads of the Department and the Directors of the above mentioned Centers for their collaboration, as well as all the medical directors, psychologists, nurses, health operators, and others who kindly collaborated for the realization of this study.

We also thank Dr. Simona Napoletano, Specialized in Legal Medicine at Sapienza University of Rome, who cooperated in analysing the protocols relevant to the present study. 


\section{The victims}

The average age of the victims was 51 years for males and 40 for women. The victims under study were subdivided into: 11 single/unmarried (37\%), 4 divorced (13\%), 15 married/cohabiting $(50 \%)$; the educational level ranges from medium to high, being this study conducted in a health context. The victims were: 18 psychiatrists $(60 \%), 3$ psychologists $(10 \%), 9$ nurses $(30 \%)$. The victims' average age at the time of stalking was 40 years for females and 51 for men. Three victims declared that stalking had taken place during the years of specialization (28/33 years). The average length of service of the interviewed victims was 22 for males, and 18 for females.

\section{The Stalkers}

As for the molesters: the stalkers were 22 males (73\%) and 8 females $(27 \%)$. In 23 cases $(77 \%)$ the stalkers are patients or expatients followed by a professional, in 4 cases (14\%) a family member of the patient (husband/brother), in 3 cases (10\%) the type of relationship with the stalker has not been specified. The age of male stalkers divided by age groups was found to be in 4 cases between 18 and 30 years, in 6 cases between 30 and 40 years, in 5 cases between 40 and 50 years, in 7 cases more than 50 years. The average age of male stalkers at the end of stalking was 41 years.

The age of female stalkers divided by age groups was: 2 cases between 18 and 30 years, 4 cases between 30 and 40 years, 1 case between 40 and 50 years, 1 case more than 50 years. The average age of female stalkers at the end of stalking was 38 years.

Regarding the marital status in 18 cases ( $60 \%$ of the sample) the stalker was single/unmarried ( $15 \mathrm{M}, 50 \% ; 3 \mathrm{~F}, 10 \%)$, 4 were married $(13 \% \mathrm{M}), 2$ were divorced $(7 \% \mathrm{M}), 1$ was engaged $(3 \%)$. The marital status of female stalkers was: 3 unmarried $(10 \%), 3$ married $(10 \%)$, 1 was cohabiting (3\%), and 1 was the girlfriend (3\%).

The education level detected in males was: 11 cases had middle school diploma (37\%), 2 (7\%) high school diploma, 5 university

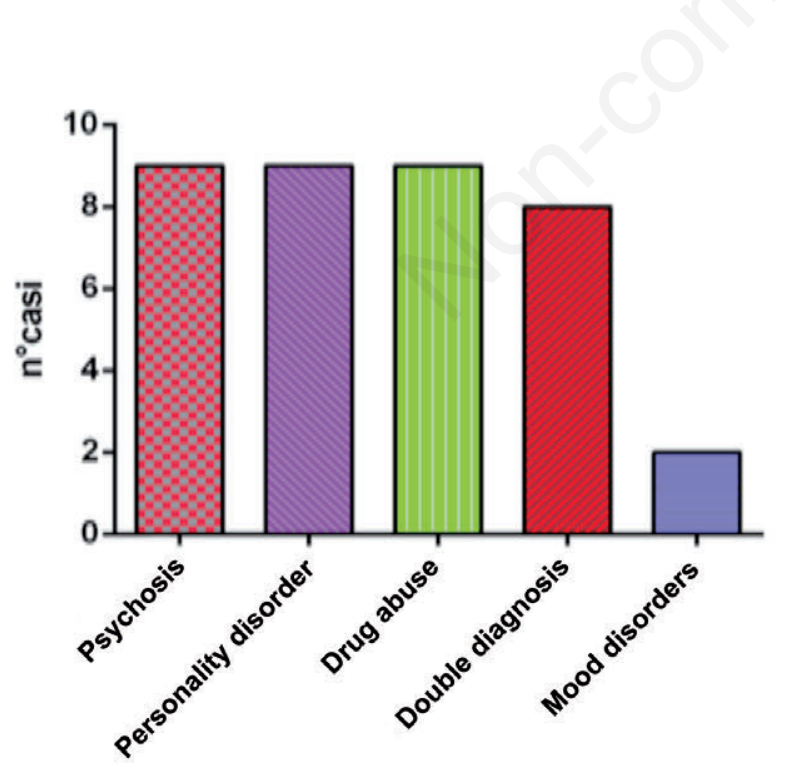

Figure 1. Stalker diagnosis (male). The most prevalent psychiatric diagnoses in male stalkers were: 9 Substance Use Disorder, 9 Psychosis (30\%), 9 Personality Disorder (30\%), 2 Mood Disorder $(7 \%) ; 8$ stalkers had a Double Diagnosis $(27 \%)$. degree (17\%), and 1 case (3\%) elementary school diploma. Among the female stalkers, $3(10 \%)$ had middle school diploma and $5(17 \%)$ high school diploma.

Regarding the psychiatric diagnosis in male stalkers, the following data have been detected: 8 molesters had a double diagnosis (27\%); 9 (30\%) had a diagnosis of Substance Use Disorder, among them 5 cases (17\%) reported alcohol use, 2 (7\%) use of light drugs, 4 (13\%) use of heavy drugs, 4 (13\%) drug abuse, 1 case $(3 \%)$ sexual addiction. Nine stalkers had a diagnosis of Psychosis (30\%), two of whom had co-morbidity with a Substance Use Disorder, and in one case also with an Anxiety Disorder. Nine stalkers had a diagnosis of Personality Disorder (30\%), six cases presented comorbidity with substance use disorder, one case also Mood and Psychosis Disorder, or only Mood Disorder. The diagnosis of Mood Disorder has been detected in 2 stalkers (7\%) (Figure 1).

As for the diagnoses of female stalkers: $3(10 \%)$ had a diagnosis of Mood Disorder (two diagnoses of Bipolar Disorder), one (3\%) in co-morbidity with Borderline Personality Disorder, another a diagnosis of co-morbidity with Substance Use Disorder. Only one stalker (3\%) was affected by Psychosis in co-morbidity with Substance Use Disorder, 3 stalkers (10\%) had Personality Disorder, one of them in co-morbidity with Substance Use Disorder, and one in co-morbidity with Substance Use Disorder and Anxiety Disorder, and one in co-morbidity with Adaptation Disorder. In total, 4 female stalkers have a double diagnosis $(13 \%)$, and 4 a diagnosis of Substance Use Disorder (13\%) (Figure 2).

\section{Molester-molested dyad}

Although in the majority of cases $(77 \%)$ molesters persecute healthcare workers of the opposite sex, in $23 \%$ of cases the molester-molested dyad is of the same sex.

In 3 cases, female healthcare worker is harassed by a female patient with a Personality Disorder (Borderline, in one case in co-

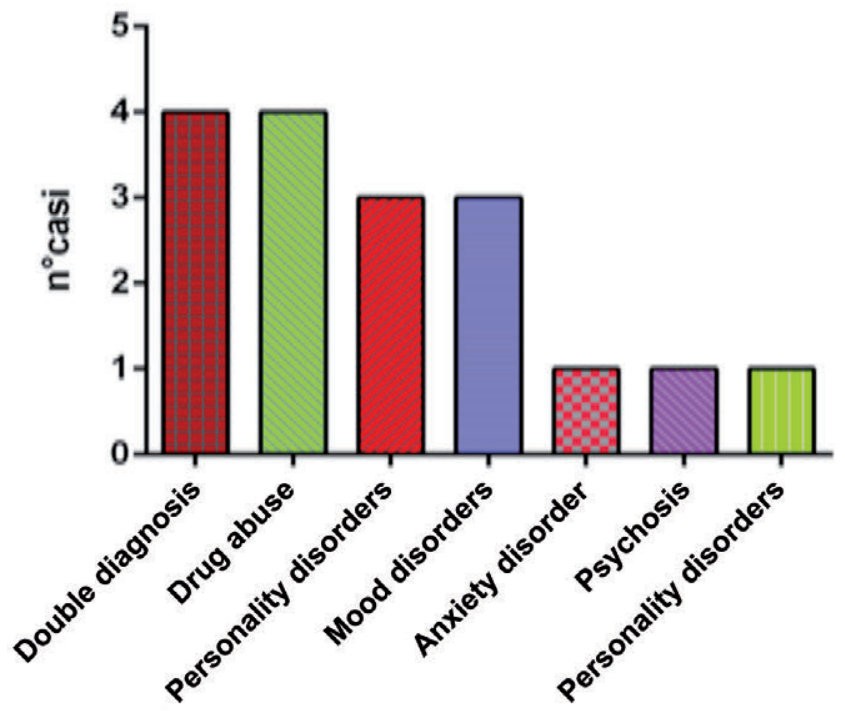

Figure 2. Stalker diagnosis (female). Among female stalkers, 3 had a diagnosis of Mood Disorder $(\mathbf{1 0 \%}), 3$ of Personality Disorder (10\%), 4 Substance Use Disorder (13\%), 4 Double Diagnosis $(13 \%)$. 
morbidity with Bipolar Disorder; in 3 cases male professional is harassed by a patient of the same sex with Psychosis (Delusional Disorder, in one case by a stalker affected by Mood Disorders, Substance Use Disorder, Personality Disorder). These data slightly differ from what reported in literature showing that in almost all cases men adopt persecutory behaviours only towards female victims, while almost all women analyzed can persecute both women and men. Women are more likely to stalk against members of the same sex than men (Ostermeyer B. et al., 2016).

There are no significant gender differences regarding the mode of persecution used. The most frequently used methods by female stalkers are phone calls, but have been also reported cases of marked physical aggression toward the same sex with attempted strangulation of the victims and destruction of their material objects with attempts to set fire to some of their documents, stalking at the healthcare professional's workplace and at home. The harassment length in female stalkers appears to be rather long lasting, generally over a one-year period.

\section{Stalking impact}

According to literature, the impact of stalking on the health of the persecuted person is often relevant in terms of biological damage; in fact, exposure to this particular form of violence can have repercussions on the individual different aspects (physical, psychological, social) with consequences on the quality of life (Buzzi F. et al., 2014, p. 2018).

From a social point of view, the deleterious effect of harassing harassments on victims of stalking has been reported over time by several clinical studies showing how victims have to make significant changes in their lifestyle by restricting their social activities, reducing their work commitment, losing additional working days lost for fear of going to work, undergoing counselling or medical treatment, going to court, or making a complaint to the police. They also report a decline in work performance due to stress, and the need to ask to be moved to another workplace in an attempt to escape the stalker (Galeazzi G.M. and Curci C., 2003). Frequently the victims report feeling a sense of loss of control and persistent threat or mobbing (Galeazzi G.M. and Curci C. 2003 from Hall D.M., 1998).

From the physical point of view, the victims often report onset of disorders related to stress conditions, such as: insomnia, increased use of alcohol and smoking, changes in appetite, digestive and psychosomatic disorders (Buzzi F. et al., 2014, p. 208), and frequently complain about worsening of pre-existing medical conditions such as asthma and arterial hypertension (Galeazzi G.M. and Curci C., 2003).

From the psychic point of view, the experience of stalking determines the most significant negative effects: the symptoms may have a transitory duration, but may also become permanent (Buzzi F. et al., 2014, p. 209). As reported in literature (Buzzi F. et al., 2014, p. 209 from Hall 1998), the most frequent psychopathological features are anxiety disorders (phobias, panic attacks), Post Traumatic Stress Disorder (PTSD) especially in case of violence. In this regard some studies carried out with standardized questionnaires, report in more than $37 \%$ of the victims interviewed an intensity of their symptoms comparable with those of the victims of traumatic events, such as traffic and air accidents, robberies, etc. (Buzzi F. et al., 2014, p. 209 from Kamphuis J. H. and Emmelkamp M. E. 2001). The prognosis of PTSD is favourable in the cases of early onset of symptoms, but unfavourable in cases of delayed onset.

In our research, as a result of the harassing harassment, physical and psychic symptoms have been reported. The psychic symptoms complained by the victims of stalking were: fear ( $50 \%$ of cases), frequently also anger (47\%), 8 cases loss of concentration (27\%), 7 cases confusion (23\%), 2 cases anxiety (7\%). Only 3 victims $(10 \%)$ did not report any psychic symptoms, while 2 reported paranoia $(7 \%)$ aggressiveness, and $2(7 \%)$ depression. One victim (3\%) reported pronounced PTSD associated with Mood Disorder and suicidal thoughts (3\%). Regarding the physical symptoms complained by the victims, 12 reported Sleep Disorders (40\%), 8 headache $(27 \%), 7$ fatigue (23\%), 5 discomfort (17\%), 5 nausea (13\%), 4 panic $(13 \%)$, 2 weakness (7\%); 9 victims reported no symptoms (30\%).

\section{Stalking}

In almost half of the total cases of harassing harassments (14, $47 \%$ ), the duration of the stalking was less than 6 months, in 6 cases (20\%) the harassment was 1-2 years, in 5 cases (17\%) between 6 months and 1 year and in other 5 cases $(17 \%)$ the duration of harassment was more than 2 years. Stalking intensity was subjectively perceived by the mental health professionals in 14 cases (47\%) of medium intensity, in $10(30 \%)$ of mild intensity, in $4(13 \%)$ of severe intensity, in 2 (7\%) severely debilitating. As regards the persecution method used, the poly-modality used by the stalkers has been remarkable: in 14 cases (47\%) 3 or more than 3 different harassment modalities have been used; in 9 cases (30\%) 2 types of persecution, in 7 cases $(23 \%)$, only one persecution mode was used.

The most frequently methods used for harassing harassment have been: first, phone calls in $83 \%$ of the sample ( 25 cases); secondly, verbal threats (13 cases) (43\%). Researches indicate that the percentage of threats suffered by the victims of stalking ranges between 29 and $41 \%$, while higher values have been reported in the statistics developed in the forensic field (Galeazzi GM and Curci C., 2003). In the third place, the following has been reported: 9 ambushes at the workplace (30\%), 9 at home (30\%,), 3 denigration (10\%), 3 declarations of love $(10 \%)$. Other 10 cases $(33 \%)$ refer to: 3 damages to objects (10\%), 2 serious physical aggressions (7\%), 2 car chases (7\%), 1 request for a meeting and sexual relations (3\%), 1 gift extended also to the victim's family members, (3\%), 1 cyberstalking ( $3 \%$ ). In 3 cases $(10 \%)$ the stalking was perpetrated involving third parties (stalking by proxy). Sometimes the stalkers resort to third parties for the persecution of their victim, in order to increase harassing harassment or continue the harassment when the judicial authority has issued a sentence against such stalking.

\section{Measures to combat stalking}

With regard to the stalking contrast measures most frequently adopted by the harassed health workers, multiple contrast methods have been used in 12 cases ( $40 \%$ of the victims), while 5 cases $(17 \%)$ have used 3 or more strategies.

Help from colleagues was requested in 10 cases $(33.3 \%)$, reporting to superiors was made in 10 cases by $33.3 \%$ of the victims, request for help from the patient's family members has been reported in 9 cases $(30 \%)$, request for help to their own family members in 2 cases $(7 \%)$, report to the police in 4 cases ( $13 \%$ of victims), 2 cases ( $7 \%$ ) have reported to the police without complaint, 2 cases $(7 \%)$ had to change job, 1 case had to leave her job for a short period of time, followed by a change of job (for reasons other than stalking), in other 2 cases the professional has asked to change the workplace. In one case of stalking it was necessary to divert all the patient's admissions to another Psychiatric Service of Diagnosis and Care; for two stalkers being followed by the Mental Health Service, the patient had to be addressed to another territorial health facility. Three cases of stalking required hospitalization, and one case a health check. Although no quantitative data were collected on the effectiveness 
of the aid sought, a considerable number of professionals appreciated the support received. However, a third of the professionals reported a feeling of impotence and isolation, frequently suffered by the victims of stalking, also highlighted by several surveys, i.e. the one by Purcell R. et al., 2005 who report that $10 \%$ of the victims interviewed had declared that they had thought of suicide as a way out.

\section{Discussion}

Our research has also highlighted that mental health professionals are high risk categories of vulnerability, especially psychiatrists and psychologists ( $70 \%$ of our sample). The studies reported in literature highlight that in most cases the author of harassment against social and health workers is a patient or an expatient, and that only in some cases it is a family member of the patient or a family member of a colleague. In our sample the stalker in $77 \%$ of cases (n. 23) was a family member of a patient or an ex-patient followed by the health professional.

In our sample victims are more frequently females (n. 23, $77 \%$ ). This datum differs from the results of other studies indicating that male healthcare workers may be at higher risk of harassment (Whyte S., 2001 from Gentile et al., 2002, Galeazzi G., 2003).

Limitation of the study is given by the low number of participants (preliminary data) and by the fact that the professionals to whom the study has been proposed and have chosen to respond, cannot be considered as representative of all the professionals of the whole Region. Another limitation is represented by the retrospective nature of the study (as in other surveys on stalking of social-health contexts reported in literature). However, as stalking is an event of considerable emotional and stressful impact, the possibility that forgetfulness due to the passing of time may lead to an underestimation of the problem appears limited (Whyte S., 2001).

Several studies report a considerable reluctance to reveal stalking by those used to consider their profession in terms of help, especially if the patient is affected by a mental disorder. Some professionals fear that revealing to be victims of harassment by a patient may be considered a sign of incompetence, low professionalism, or that a previous involvement with such patient may be suspected (Acquadro DM et al., 2014).

As highlighted by Curci C. et al., 2003 (Assaulting Harassment Syndrome, p. 118) when stalking behaviour concerns a healthcare worker, a conflict of interests arises between therapeutic and institutional tasks that lead to safeguard the relationship with the patient and develop the need to distance himself from the molester. The reactions of psychiatrists, who are stalked by a patient (or someone else), are likely to be influenced by their interpretation of the motivations behind stalking. There is no evidence showing that psychiatrists are more or less likely to have negative psychological or psychiatric consequences than other victims of stalking. However, they could be perceived as less vulnerable and, therefore, receive less support (Maclean L. et al., 2013).

Analyzing the entire sample, the type of violence that has been most prevalent in our sample was that of a psychologicalrelational type, as indicated by the results of other similar studies. This is also relevant, considering the consequences on this particular type of victims, the "health professionals" who, due to the role they are called to play in their working contexts, need serenity, emotional and psychological stability (Grattagliano N. et al., 2014 from Hirigoyen M.F., 2005). Regarding the lower rate of violence highlighted in various studies on stalking in the professional field $(7.5 \%)$ compared to the rates of violence reported in the psychiatric-forensic contexts (eg Meloy in a study carried out in 1999 reports a frequency of aggression of 30-40\%) (Galeazzi G.M. and Curci P., 2003 from Meloy 1999), it can be hypothesized that they can influence the ability of both the professional and the healthcare team to contain stalking; furthermore, it is assumed that the healthcare worker tends to minimize the phenomenon as a mechanism of professional coping (Galeazzi G.M. and Curci P., 2003).

Regarding the physical, biological and psychological damages complained by the victim, the data obtained in our research seem to comply with those reported in literature. The severity of the psychopathological disorders is proportional to the intensity and duration of the harassment (Buzzi F., et al., 2014).

\section{Conclusions}

Several professionals in the social-health field seem to be poorly informed about stalking and its consequences (Pomilla A. et al., 2012, Praus P. et al., 2017). Therefore, more information, awareness and education on the phenomenon would be appropriate. Such information should be provided also during specialization due to the chance that trainees and specializing students might be subjected to harassing harassments (in our sample: 3 cases) as pointed out by some authors (Galeazzi GM and Curci C., 2003 from Lion J.R. et al.1998). These data have not been confirmed by other studies reporting that younger psychiatrists are under represented among those who claim to be victims of stalking, thus disproving the hypothesis that stalking perpetrated by patients may be due to the victim's inexperience or mistakes (Whyte S. et al., 2001).

Therapists sensitized on the "problematic" behaviours of patients should consider whether there is any relationship even at the level of the personal vulnerability between stalkers and victims (Praus P. et al., 2017). Some preventive measures should be taken to avoid stalking and the entire team should be trained to face the potential stalker. Nurses also who are exposed to becoming victims of stalking (Praus P. et al., 2017 from Acquadro D.M., 2010), although to a lesser extent than psychiatrists and psychologists, should be trained as well, as highlighted in our research.

It is essential that the relationship with the patient is always maintained on a strictly professional level and that, at the first signs of violation of the setting, proper measures, such as reducing the frequency or duration of the visits, are taken (Merzagora Betsos I. et al. 2010 from Galeazzi G.M. and De Fazio 2006). If these strategies are not suitable for combating the harassment, several authors agree that every occasion for communication, meeting, negotiation, discussion or attempt to convince (Merzagora Betsos I. et al., 2010) should be avoided. Some studies report that a few practitioners continue to treat the patient despite being harassed: this appears not only as an inappropriate tolerance against the antisocial behaviours of these patients, but also an unprofessional attitude of therapists who put their own life at risk (Praus P. et al., 2017). In case of stalking, $25 \%$ of clinicians do not ask for any kind of assistance (Ostermeyer B., 2016 from Whyte S., 2011).

As reported by Praus P. et al., 2017, clinicians should: 1) report as soon as possible cases of stalking perpetrated by patients; 2 ) should stalking occur, it is advisable to change the healthcare operator; 3) to introduce further measures (legal, ad example) on individual cases and carry out an analysis of the possible risks; 4) the field operators (psychiatrists and so on) should periodically 
update their knowledge on the phenomenon of stalking and be trained on how to behave if they have to face this type of situation.

\section{References}

Acquadro Maran D., Varetto A., Zedda M., (2014), Italian Nurses' Experience of Stalking: A Questionnaire Survey, Violence and victims, 29 pp: 109-121, vol. 1, DOI: 10.1891/0886-6708.VVD-12-00078, Italian nurses' experience of stalking: a questionnaire survey, Manuscript Number: VV-D-12-00078.

Alfarano E., La Tegola D., Carabellese F., Catanesi F., (2012), Stalking al femminile: una rewiew di letteratura, Rassegna italiana di criminologia, 1/2012, pag. 22.

Alfarano E., La Tegola D., Carabellese F., Catanesi F., (2012), da Gentile, S.R., Asamen, J.K., Harmell, P.H., \& Weathers, R. (2002), The stalking of psychologists by their clients, Professional Psychology, Research and Practice, 33, 490-494; in Stalking al femminile: una rewiew di letteratura, Rassegna italiana di criminologia, 1/2012, pag. 26.

Buzzi F., Vanini M., (2014), Guida alla valutazione psichiatrica e medico legale del danno biologico di natura psichica, Giuffrè Editore.

Buzzi F., Vanini M., (2014), da Hall, D. M., The victims of stalking, in J.R. Meloy, The psychology of stalking: clinical and forensic perspectives, Academic Press, San Diego 1998.

Buzzi F., Vanini M., (2014) da Kamphuis J.H., Emmelkamp M.E., (2001) Traumatic Distress among support-seeking female victims of stalking, Am. J. of Psychiatry 158, 795-798.

Caretti V., Ciulla S., Schimmenti A., (2011), Stalking definizione del costrutto, aspetti fenomenologici, comportamenti associati, Giorn Ital Psicopat; 17:5-12.

Catanesi R., Carabellese F., La Tegola D., Alfarano E., (2013), Coexistence and Independence Between a Mental Disorder and Female Stalking, J Forensic Sci, January 2013, Vol. 58, No. 1 doi: 10.1111/j.1556-4029.2012.02210.

Da Sacco E., (2015) da Gagliardi M., Battistini I.A., La Via V., MerzagoraBetsos I., (2013), Psicologi vittime di stalking, in Ricerche di Psicologia, 36, 445-463; in La sindrome delle molestie assillanti, Piesse, anno 1. n. 1.

Da Sacco E., (2015) da Purcell R., Powell M.B. and Mullen P.E., (2005), Clients who stalk psychologists: prevalence, methods, and motives. Professional Psychology: Research and Practice36: 537-543, in La sindrome delle molestie assillanti, Piesse, anno 1. n. 1.

Dressing H., Scheuble B., Gass P. Stalking (2006): a significant problem for patients and psychiatrists. Br J Psychiatry; 189: 566-7.

Farnham F., James D., Cantrell P., (2000), Association between violence, psychosis, and relationship to the victim in stalkers. Lancet; 355:19.

Galeazzi G.M., Curci P., Secchi C., (2003), La sindrome delle molestie assillanti (stalking), Manuali di Psicologia, Psichiatria, Psicoterapia, Bollati Boringhieri.

Galeazzi G.M., Curci P., Secchi C., (2003), da Hall D.M., (1998) The victims of stalking, The Psychology of stalking: clinical and forensic perspectives, Academic Press, San Diego.

Galeazzi G.M., Curci P., Secchi C., (2003), da Lion J.R. et al. The Stalking of Clinicians by their patients, in Meloy (1998); in La sindrome delle molestie assillanti (stalking), Manuali di Psicologia, Psichiatria, Psicoterapia, Bollati Boringhieri.

Galeazzi G.M., Curci P., Secchi C., (2003) da Meloy (1999) Stalking: an OldBehavior, a New Crime, Psychiat. Clin. North
Am., vol. 22, 85-99, in La sindrome delle molestie assillanti (stalking), Manuali di Psicologia, Psichiatria, Psicoterapia, Bollati Boringhieri.

Grattagliano I., et al., (2014), Stalking nei confronti di operatori di contesti socio-sanitari: risultati preliminari di una ricerca nella Regione Puglia, Stalking of social healthcare workers: preliminary results of a study conducted by the region of Apulia, Italy, Rivista di psichiatria, 2014, 49 (6): 273-278.

Grattagliano I., et al., (2014), da Hirigoyen M.F. Molestie morali. La violenza perversa nella famiglia e nel lavoro. Torino: Einaudi, 2005 in Stalking of social healthcare workers: preliminary results of a study conducted by the region of Apulia, Italy, Rivista di psichiatria, 2014, 49 (6): 273-278.

McEwan T.E., Strand S., (2013), da Abrams K.M. and Robinson G.E. (2011) Stalking by patients: doctors'experiences in a Canadian urban area. Journal of Nervous and Mental Disease 199:738-743; e da Morgan R. K and KavanaughK. D. (2011) Student stalking of faculty: Results of a nationwidesurvey, College Student Journal 45:512-523; e da Purcell R., Powell M.B. and Mullen P.E., (2005) Clients who stalk psychologists: prevalence, methods, and motives. Professional Psychology: Research and Practice 36:537543, in The role of psychopathology in stalking by adult strangers and acquaintances, Australian \& New Zealand Journal of Psychiatry 47:546-555.

McEwan T.E., Strand S., (2013), da James D.V., Mullen P., Pathé M., et al. (2009) Stalkers and harassers of royalty: The role of mental illness and motivation. Psychological Medicine 39: 1479-1490; in The role of psychopathology in stalking by adult strangers and acquaintances, Australian\& New Zealand Journal of Psychiatry 47:546-555.

Maclean L. MSc, Reiss D., Seán Whyte, Christopherson S., Petch E., and Penny C., MD, (2013), Psychiatrists' Experiences of Being Stalked: A Qualitative Analysis, J Am Acad Psychiatry Law 41:193-9.

Mastronardi V., Ricci S., Pomilla A., (2013), Stalking of psychiatrists: psychopathological characteristics and gender differences in an Italian sample. Int $\mathrm{J}$ offender Ther Comp Criminol; 57(5):526-43.

Merzagora Betsos I., Muttillo G., Travaini G.V., (2010), Lo stalking e l'infermiere, in L'infermiere 2/2010, pag. 23-24.

Merzagora Betsos I., Muttillo G., Travaini G.V., (2010), da Galeazzi G.M., De Fazio L. (2006), A review on the stalking of mental health professionale by patients, prevention and management issues, Primary Care and Community Psychiatry 11:57-66; in Lo stalking e l'infermiere, L'infermiere 2/2010, pag. 23-24.

McIvor R.J., Potter L., Davies L., (2008) Stalkingbehaviour by patientstowardspsychiatrists in a large mentalhealthorganization, Int J SocPsychiatry; 54:350-7, citato da Ostermeyer et al. 2016 pag. 270; Praus P. et al. 2017; e in McEwan T.E. e Strand S. 2013.

Ostermeyer B., et al. (2016), da Hughes F.A., ThomK., Dixon R., (2007) Nature and prevalence of stalking among New Zeland mental health clinicians. J Psychosoc Nurs mental health serv, 45:32-9, in Stalking and Violence. Psychiatr Clin North Am. 39:663-673.

Ostermeyer B., et al., (2016), da McIvor R.J., Potter L., Davies L., (2008) Stalking behaviour by patients towards psychiatrists in a large mental health organization, Int J Soc Psychiatry; 54:350-7 in Stalking and Violence, Psychiatr Clin North Am. 39:663-673.

Ostermeyer B. et al., (2016), da Meloy J. e Boyd C., (2003), "Female stakers and their victims", Journal of the American Academy of Law and Psychiatry, in Stalking and Violence, Psychiatr Clin North Am. pag. 65.

Ostermeyer B. et al., (2016), da Whyte S., Penny C., Christopherson S. et al., (2011), The stalking of psychiatrists. Int J. Forensic 
Ment Health; 10:254-60, in Stalking and Violence, Psychiatr Clin North Am.

Pathé M., et al. (2002), Surviving stalking, Cambridge, UK: Cambridge University, Press.

Praus P., Riedel-Heller S., Dressing H., (2017), da Aquadro M.D., Pristerà V., Zedda M., (2010) Stalking: aspetti psicologici; psicologi a confronto, anno 4, n.2, ottobre, in Stalking of psychiatrists and psychotherapists: result of an online survey, Der Nervenarzt.

Pomilla A., D'Argenio A., Mastronardi V., (2012), Stalking: considerazioni clinico-criminologiche tramite i risultati di un contributo di ricerca, Supplemento alla Rivista di psichiatria, 47,4.

Praus P., Riedel-Heller S., Dressing H., (2017), Stalking of psychiatrists and psychotherapists: result of an online survey, Der Nervenarzt.

Praus P., Riedel-Heller S., Dressing H., (2017), da Farber S.K., (2015), My patient, my stalker empathy as a dual-edged sword: a cautionary tale. Am J. Psychother 69 (3):331-356, in Stalking of psychiatrists and psychotherapists: result of an online survey, Der Nervenarzt.

Praus P., Riedel-Heller S., Dressing H., (2017), da Mcewan T.E., Mackenzie R.D., Mullen P.E., et al., (2014), Stalking: Ein Leitfaden zur Risikobewertung vonStalkern, das Stalking Risk Profile, Kohlhammer, Stuttgart; in Stalking of psychiatrists and psychotherapists: result of an online survey, Der Nervenarzt.

Praus P., Riedel-Heller S., Dressing H., (2017), da Sandberg D.A., Mcniel D.E., Binder R.L., (2002) Stalking, Threatening, and Harassing Behavior by Psychiatric Patients Toward Clinicians, in Journal of the Academy of Psychiatry and the Law, 30, 221229 in Stalking of psychiatrists and psychotherapists: result of an online survey, Der Nervenarzt.

Purcell R., Pathé M., Mullen P.E., (2001), A study of women who stalk. American Journal of Psychiatry, 158:2056-2060.

Purcell R., Powell M.B., Mullen P.E., (2005), Clients who stalk psychologists: prevalence, methods, and motives. Professional Psychology: Research and Practice 36: 537-543, citato in McEwanT.E. e Strand S. (2013).

Racine C., Billick S., (2014), Classification Systems for Stalking Behavior, J Forensic Sci, January, Vol. 59, Nos.

Sorrentino R., Hatters Friedman S., Ostermeyer B., et al., (2016), An update on stalkers and their victims, Newsl Am Acad Psychiatry Law; 41(1):23-7.

Strand S., McEwan T.E., (2011), Same gender stalking in Sweden and Australia. Behav Sci Law; 29: 202-19.

Stefanelli M., (2011), "Lo stalker: Profili e trattamento", in Psicoterapeuti in formazione n. 7.

Whyte S., Penny C., Christopherson S., et al., (2011), The stalking of psychiatrist in J.Forensic Ment Health, 10:254-60.

Whyte S., Penny C., Christopherson S., et al., (2011), The stalking of psychiatrist in J. Forensic Ment Health, 10: 254-60 da Galeazzi G.M., Elkins, K., \& Curci, P. 2005, Emergency psychiatry: The stalking of mental health professionals by patients. Psychiatric Services, 56, 137-138. e da Gentile, S.R., Asamen, J.K., Harmell, P.H., \& Weathers, R. 2002. The stalking of psychologists by their clients. Professional Psychology: Research and Practice, 33, 490-494.
Correspondence: Francesca Manunza.

E-mail: manunzaf@gmail.com

Key words: Stalking, harassing harassment, healthcare workers, victimization.

Parole chiave: Stalking, molestie assillanti, operatori socio-sanitari, vittimizzazione.

Palabras clave: Stalking, hostigar acoso, operadores sociales, victimización.

Received for publication: 13 March 2018.

Revision received: 18 April 2018.

Accepted for publication: 20 April 2018.

Conference presentation: Part of this article was presented to the " $1{ }^{\circ}$ Congresso Nazionale dell'Accademia Italiana di Criminologia, Sistema Penale, Investigazioni e Sicurezza" 27-29 April 2018, Rome Italy.

This article is distributed under the terms of the Creative Commons Attribution Noncommercial License (by-nc 4.0) which permits any noncommercial use, distribution, and reproduction in any medium, provided the original author(s) and source are credited.

(C) Copyright F. Manunza et al., 2018

Licensee PAGEPress, Italy

Rivista di Psicopatologia Forense, Medicina Legale, Criminologia 2018; $23: 28$

doi:10.4081/psyco.2018.28 